\title{
Editorial
}

\section{Special issue on love and sex with robots}

\author{
Simon Dubé ${ }^{\mathrm{a}, \mathrm{b}}$ and David Levy ${ }^{\mathrm{c}, *}$ \\ ${ }^{a}$ Concordia Vision Laboratory, Center for Studies in Behavioral Neurobiology, Department of \\ Psychology, Concordia University, Montréal, Canada \\ ${ }^{\mathrm{b}}$ Research on Sex, Violence, \& Personality Laboratory, Department of Psychology, McGill \\ University, Montréal, Canada \\ ${ }^{\mathrm{c}}$ London NW3 2LD, United Kingdom
}

The study of love and sex with robots is a steadily growing academic discipline within the transdisciplinary field of Social Robotics. This growing discipline is increasingly approached through various perspectives, ranging from Human-Machine Interaction, Robotics, and research on Artificial Intelligence and Life, to Humanities, Social, Human, and Health Sciences, as well as Queer, Feminist, and Critical Studies. This area of research can trace its origins to seminal contributions, such as Dr. David Levy's successful defence of the $\mathrm{PhD}$ thesis entitled "Intimate Relationships with Artificial Partners" in 2007, at the University of Maastricht, and the almost simultaneous publication of his book "Love + Sex with Robots" (Levy, 2007).

Prior to these seminal events, the topic of human-machine intimacy and sexuality had belonged almost exclusively to the realm of science fiction. A search using Google Scholar for the years 2000-2005 demonstrates the sparsity of occurrences of the phrase "sex with robots" in the academic literature, finding an average of only one occurrence per year for that period. In the following quinquennium, during which those groundbreaking events took place, the average number of occurrences rose to 26 per year. Between 2011 and 2015 it was 52, during 2016-2020 it was 153, and last year there were 187 such occurrences. From these statistics we observe the steady growth of academic interest in the subject. Love and sex with robots are now being addressed by the intersecting, multifaceted, and everexpanding research on technosexuality, cybersexuality, digisexuality, lovotics, and erobotics (Dubé et al., 2021).

The International Congress on Love and Sex with Robots had its premiere at the University of Madeira in 2014, and is now an annual event in the conference calendar. This special issue of the Journal of Future Robot Life provides a collection of papers from the $5^{\text {th }}$ congress, held in 2020, plus some additional papers submitted to this journal. In this special issue, Brandon and colleagues explore how demographics - such as gender - influence people's attitudes and opinions toward sex robots. Ono and colleagues present a prototype of a system that can generate new stories pertaining to love and sex - a system which may form the basis of future artificial agents in more interactive robotic psychotherapy. And Marečková and colleagues examine the prevalence of desire for sex robots in minor-attracted men, subjects sexually interested in non-consent/violence against adults, and a control group from a representative Czech sample.

\footnotetext{
*Corresponding author. E-mail: davidlevylondon@gmail.com. 2589-9953 @ 2022 - The authors. Published by IOS Press. This is an Open Access article distributed under the terms of the Creative Commons Attribution-NonCommercial License (CC BY-NC 4.0).
} 
In this special issue, van Voorst also investigates sexdoll-intimacy for heterosexual females through two anthropological case studies: one in which the author personally rented a male sexdoll, and another in which the author observed and interviewed a sexdoll-owner interacting with her doll at home. Eriksson explores the issues that may arise from romantic and sexual interactions with virtual humans using Design Fiction, a form of dramatized story which speculates and critically reflects on the risks and benefits of future technology. And Schussler examines human-sexbot and sexbot-sexbot relationships through an Objected-Oriented Ontology perspective, deconstructs human-centric approaches to (techno)eroticism, and emphasizes how erobots - artificial erotic agents - invite a paradigm shift in our conceptualization and experience of our intimacy and sexuality with humans and machines.

Finally, Marchant and Climbingbear examines the United States' legal response to sex robots and focuses on the strategies that are (or could be) used to prohibit or restrict the commercialization, availability, and/or use of these machines. Sætra explores whether robots made for companionship and love can change our very understanding of love. And Musiał and Malinowska discusses naturalistic and antinaturalistic interpretations of why people experience emotions towards robots and tend to treat them as animate, and propose that these interpretations should be considered complementary rather than contradictory.

This special issue and its articles are both important and timely. In a world where technology occupies an ever-growing place in our eroticism, and robots with sociosexual capabilities are being developed, it becomes imperative to reflect on the interacting and co-evolving meanings, experiences, and impacts of human-machine intimacy and sexuality. This reflection requires a transdisciplinary approach, one that is at the core of this collection of excellent papers. The advent of highly sophisticated artificial companions may still be in the future, but the study of love and sex with robots is now.

\section{REFERENCES}

Dubé, S., Santaguida, S., Anctil, D., Leshner, C., Vachon, D. \& Johnson, A. (2021). Technology-based sexualities. In A.D. Lykins (Ed.), Encyclopedia of Sexuality and Gender. Springer. doi:10.1007/9783-319-59531-3_70-1.

Levy, D. (2007). Love and Sex with Robots: The Evolution of Human-Robot Relationships. New York: Harper Collins. 